\title{
Efficiency of HPV DNA Test versus Pap Smear in the Screening of Cervical Cancer
}

\author{
Pradhan R, ${ }^{1}$ Pant $U,{ }^{1}$ Aryal B ${ }^{2}$ \\ ${ }^{1}$ Department of Obstetrics and Gynecology, Patan Academy of Health Sciences, Lalitpur, Nepal, \\ ${ }^{2}$ Department of Obstetrics and Gynecology, Karnali Academy of Health Sciences, Jumla, Nepal.
}

\section{Corresponding Author: \\ Dr Renee Pradhan}

Patan Academy of Health Sciences, Lalitpur, Nepal

Email:pradhanrenee@gmail.com

\begin{abstract}
Introduction: Cancer cervix is a common genital cancer. Human papillomavirus is the main cause of cervical cancer because of the strong association of certain HPV genotypes and the development of cervical cancer and its precursor lesions, cervical intraepithelial neoplasia CIN 2 or CIN3.

Methods: The study was conducted on 180 gynecological patients seen at the outpatient department of Manipal Hospital, Bangalore. A comparative study of HPV DNA test with Pap smear in the screening of cervical neoplasia was carried out over the period of 24 months from August 2011 to June 2013.

Results: The incidence of cervical cancer and its associated mortality has declined in recent years, largely due to the widespread implementation of screening programs by Pap smear testing. The management and the prevention of cervical cancer should change with HPV DNA testing for high risk HPV, which is more sensitive than pap smear testing. Infection of cervix with HPV is necessary to cause cervical neoplasia and cervical cancer. Persistent infection with HPV is required for the development of cervical dysplasia and invasive cervical cancer.

Conclusions: HPV testing alone for primary screening appears promising in women aged 30 years and older as this group is at greatest risk of developing CIN 3. As compared with Pap testing, HPV testing has greater sensitivity for detection of cervical intraepithelial neoplasia

Keywords: colposcopy; HPV DNA; HSIL; LSIL; pap smear; screening.
\end{abstract}

\section{INTRODUCTION}

Cancer cervix is the most common gynecological malignancy and third most common malignancy in women after breast and colorectal cancers. It constitutes about $12 \%$ of all malignancies in women. Highest incidence of carcinoma is reported in Cali, Colombia $(52 / 100,000)$ and lowest in Kuwait $(3 / 100,000) .{ }^{1}$ Early detection of pre-invasive disease and treatment of CIN has the potential to improve the outcome of patients. Invasive cancer of cervix is considered to be a preventable condition, since it is associated with a long pre-invasive stage (CIN), making it amenable to screening and treatment.

Cervical cancer, which develops from cervical intraepithelial neoplasia (CIN), is an important cause of death in women worldwide. The introduction of Pap smear test decades ago has reduced the incidence of cervical cancer in most developed and some developing countries as well. Although Pap test has the merits of being convenient, reasonably specific and inexpensive, concern about the low sensitivity of the Pap smear test in detecting cervical cancer lesions has prompted a search for newer methods to either supplement or replace it. A low sensitivity of Pap test would put women at risk to develop invasive cervical cancer. In view of importance of human papillomavirus (HPV) in the etiology of cervical cancer, HPV DNA testing which allow women to be classified as high-risk HPV positive or negative could be used as an adjunct to Pap test. ${ }^{2}$

\section{METHODS}

This was a randomized, prospective study, conducted on 180 gynecological patients seen at Outpatient Department of Gynecology / Obstetrics and Department of Oncology, Manipal Hospital, 
Bangalore to compare HPV DNA test with Pap smear in the screening of cervical neoplasia (CIN I, CIN II, CIN III and Squamous Cell Carcinoma).

Study was conducted over the period of 24 months from August 2011 to June 2013.The history of each patient was obtained following which a general physical and gynecological examination was performed. All patients underwent routine cervical smear cytology and HPV DNA test. Pap smear in women aged more than 30 years is done routinely as the protocol of the hospital. For HPV DNA test, consent was taken in high risk patients, example women with contact bleeding, recurrent vaginal discharge, hypertrophied cervix and cervical erosion on clinical findings.

Inclusion Criteria were women who were sexually active women and more than 30 years coming to OPD for gynecological checkup.

Those who were: menstruating/active vaginal bleeding, pregnant women, inaccessible cervix (due to cervical stenosis or cervix is flushed with vagina), 24 hours of use of vaginal cream/pessary/ sexual intercourse, women who had undergone hysterectomy were excluded.

The Statistical software namely SAS 9.2, SPSS 16.0, Stata 10.1, MedCalc 9.0.1, Systat 12.0 and $\mathrm{R}$ environment version .2.11.1 were used for the analysis of the data and Microsoft word and Excel have been used to generate graphs, tables etc.

\section{RESULTS}

\begin{tabular}{|c|c|c|c|c|c|c|}
\hline \multirow{2}{*}{$\begin{array}{l}\text { Age } \\
\text { in } \\
\text { years }\end{array}$} & \multirow{2}{*}{$\begin{array}{l}\text { No. of } \\
\text { Pati } \\
\text { ents }\end{array}$} & \multicolumn{4}{|c|}{ No. of patients with } & \multirow{2}{*}{$\begin{array}{l}\text { No. of } \\
\text { patients } \\
\text { with CIN } \\
(\%)\end{array}$} \\
\hline & & $\begin{array}{l}\text { CIN } \\
\text { I }\end{array}$ & $\begin{array}{l}\text { CIN } \\
\text { II }\end{array}$ & $\begin{array}{l}\text { CIN } \\
\text { III }\end{array}$ & SCC & \\
\hline $30-39$ & 92 & 8 & 4 & 1 & 0 & $13(14.13)$ \\
\hline $40-49$ & 52 & 2 & 3 & 3 & 0 & $8(15.39)$ \\
\hline $50-59$ & 26 & 3 & 0 & 1 & 1 & $5(19.23)$ \\
\hline $60-69$ & 10 & 0 & 0 & 1 & 0 & $1(10)$ \\
\hline Total & 180 & 13 & 7 & 6 & 1 & $27(15)$ \\
\hline \multicolumn{2}{|c|}{$\begin{array}{l}\text { Incidence of } \\
\text { CIN (\% in total } \\
\text { population) }\end{array}$} & 7.22 & 3.88 & 3.33 & 0.56 & 15 \\
\hline
\end{tabular}

Total detection rate of Cervical Intraepithelial Neoplasia in total 180 women was 27 (15\%), total Incidence of CIN I was $7.22 \%$, CIN II was $3.89 \%$, CIN III was $3.33 \%$ and SCC was $0.56 \%$ in total 180 women. it showed that the incidence of higher grades of neoplasia was found to increase as age increases.

\begin{tabular}{|l|l|l|}
\hline \multicolumn{3}{|l|}{ Table 2. Sexual Behaviour } \\
\hline $\begin{array}{l}\text { Sexual } \\
\text { Behaviour }\end{array}$ & $\begin{array}{l}\text { No. of } \\
\text { patients (\%) }\end{array}$ & $\begin{array}{l}\text { No. of patients with CIN } \\
(\%)\end{array}$ \\
\hline $\begin{array}{l}\text { Single Sexual } \\
\text { Partner }\end{array}$ & $175(97.22)$ & $25(14.2)$ \\
\hline $\begin{array}{l}\text { Multiple } \\
\text { Sexual } \\
\text { Partner }\end{array}$ & $5(2.78)$ & $2(40)$ \\
\hline Total & $180(100)$ & 27 \\
\hline
\end{tabular}

In the 180 women enrolled, 5 (2.78\%) women had multiple sexual partners and the majority 175 women (97.22\%) had single sexual partner. Among 175 women having single sexual partner, $25(14.2 \%)$ were detected to have CIN andamong 5 women having multiple sexual partners, 2 (40\%) were detected with neoplasia. Among the women exposed to multiple sexual partners, 2 were HPV DNA test positive. One had CIN I and 1 had CIN III. Since, the incidence of cervical neoplasia in women with multiple sexual partners is high, it is required to do HPV DNA test. 
Pradhan et al. Efficienty of HPV DNA Test Verses Pap Smear in the screening...

\begin{tabular}{|c|c|c|c|c|c|c|c|}
\hline \multicolumn{2}{|l|}{ Complaints } & No. of patients (\%) & CIN I & CIN II & CIN III & SCC & $\begin{array}{l}\text { No. of patients } \\
\text { with CIN (\%) } \\
\end{array}$ \\
\hline \multicolumn{2}{|c|}{ Routine Screen } & $61(33.89)$ & 4 & 2 & 3 & 0 & $9(14.80)$ \\
\hline \multicolumn{2}{|c|}{ White discharge per vaginum } & 77 (42.78) & 7 & 3 & 1 & 0 & $11(14.28)$ \\
\hline \multicolumn{2}{|c|}{ Contact bleeding } & $9(5)$ & 0 & 1 & 0 & 0 & 1 (11.11) \\
\hline \multicolumn{2}{|c|}{ Postmenopausal bleeding } & $8(4.44)$ & 0 & 0 & 1 & 1 & $2(25)$ \\
\hline \multirow{2}{*}{$\begin{array}{l}\text { Abnormal } \\
\text { Investigation }\end{array}$} & Abnormal Pap & \multirow{2}{*}{$10(5.56)$} & \multirow{2}{*}{3} & \multirow{2}{*}{1} & \multirow{2}{*}{0} & \multirow{2}{*}{0} & \multirow{2}{*}{$4(40)$} \\
\hline & $\mathrm{HPV}+\mathrm{ve}$ & & & & & & \\
\hline \multicolumn{2}{|l|}{ Vaginal Itching } & $6(3.33)$ & 0 & 0 & 0 & 0 & 0 \\
\hline \multicolumn{2}{|c|}{ Intermenstrual Bleed } & $5(2.78)$ & 0 & 0 & 0 & 0 & 0 \\
\hline \multicolumn{2}{|l|}{ Menorrhagia } & $2(1.11)$ & 0 & 0 & 0 & 0 & 0 \\
\hline \multicolumn{2}{|c|}{ Perineal Lesions } & $2(1.11)$ & 0 & 0 & 0 & 0 & 0 \\
\hline \multicolumn{2}{|l|}{ Total } & $180(100)$ & 14 & 7 & 5 & 1 & $27(15)$ \\
\hline \multicolumn{3}{|c|}{ Incidence of CIN (\% in total population) } & 7.78 & 3.89 & 2.78 & 0.56 & 15 \\
\hline
\end{tabular}

Majority (33.89\%) of the women attending Gynecology and Oncosurgery presented with complaints of white discharge per vaginum followed by $34 \%$ of the population who had come for routine screening. Women who had their routine screen, CIN I was detected in 4 women, 3 women had CIN III and 2 of them had CIN II. Hence total incidence of neoplasia was 9 (14.75\%). 11 (14.28\%) women presenting with white vaginal discharge were detected with neoplasia. Among 8 women having complaints of postmenopausal bleeding 2 (25\%) were detected of neoplasia. One had SCC and 1 had CIN III. Hence, postmenopausal bleeding is one of the risk factors for cervical neoplasia/ squamous cell carcinoma.

\begin{tabular}{|l|l|}
\hline \multicolumn{2}{|l|}{ Table 4. Cytology Report (Pap smear test) } \\
\hline Pap Smear & No. of patients (\%) \\
\hline Normal & $27(15)$ \\
\hline BCC & $117(65)$ \\
\hline ASCUS & $24(13.33)$ \\
\hline LSIL & $1(0.56)$ \\
\hline HSIL & $11(6.11)$ \\
\hline SCC & 0 \\
\hline AGUS & 0 \\
\hline Total & $180(100)$ \\
\hline
\end{tabular}

In the study, benign cellular changes (65\%) were the highest reported in the cytology, followed by ASCUS (13.33\%). Only 1 (0.56\%) LSIL was reported. 6.11\% women had HSIL. $15 \%$ had normal smear. No SCC/AGUS was reported in the cytology. 
Pradhan et al. Efficienty of HPV DNA Test Verses Pap Smear in the screening...

\begin{tabular}{|l|l|}
\hline \multicolumn{2}{|l|}{ Table 5. Results of HPV DNA Testing } \\
\hline Results of HPV DNA Testing & No. of patients (\%) \\
\hline Negative (-ve) & $151(83.89)$ \\
\hline Positive (+ve) & $29(16.11)$ \\
\hline Total & $180(100)$ \\
\hline
\end{tabular}

It was found that 29 (16.11\%) women among 180 in the study had HPV DNA test result positive.

Table 6. Correlation between Cervical Biopsy and HPV DNA test

\begin{tabular}{|l|l|l|l|l|l|l|l|}
\hline $\begin{array}{l}\text { HPV } \\
\text { DNA } \\
\text { Test }\end{array}$ & $\begin{array}{l}\text { Total } \\
(\%)\end{array}$ & $\begin{array}{l}\text { Chr- } \\
\text { onic } \\
\text { Cerv- } \\
\text { icitis }\end{array}$ & CIN & $\begin{array}{l}\text { CIN } \\
\text { II }\end{array}$ & $\begin{array}{l}\text { CIN } \\
\text { III }\end{array}$ & SCC & $\begin{array}{l}\text { No. of } \\
\text { patients } \\
\text { with } \\
\text { CIN } \\
(\%)\end{array}$ \\
\hline $\begin{array}{l}\text { HPV - } \\
\text { ve }\end{array}$ & $\begin{array}{l}151 \\
(83.89)\end{array}$ & 55 & 3 & 1 & 0 & 0 & $\begin{array}{l}4 \\
(2.6)\end{array}$ \\
\hline $\begin{array}{l}\text { HPV + } \\
\text { ve }\end{array}$ & $\begin{array}{l}29 \\
(16.11)\end{array}$ & 6 & 10 & 6 & 6 & 1 & $\begin{array}{l}23 \\
(79.3)\end{array}$ \\
\hline $\begin{array}{l}\text { Grand } \\
\text { Total }\end{array}$ & $\begin{array}{l}180 \\
(100)\end{array}$ & - & 13 & 7 & 6 & 1 & $\begin{array}{l}27 \\
(15)\end{array}$ \\
\hline $\begin{array}{l}\text { Incidence of CIN (\% in } \\
\text { total population) }\end{array}$ & 7.22 & 3.89 & 3.33 & 0.56 & 15 \\
\hline
\end{tabular}

Among 29 women whose HPV DNA test was positive, 23 (79.3\%) had cervical neoplasia, only $2.3 \%$ cervical neoplasia was seen whose HPV DNA test was negative.

\section{DISCUSSION}

The management and the prevention of cervical cancer should change definitely with DNA testing for high risk HPV, which is more sensitive than cytology. Infection of cervix with HPV is necessary to cause cervical neoplasia and cervical cancer. Although $80 \%$ of HPV infection clear within 2 years and does not cause cervical neoplasia, persistent infection with HPV is required for the development of cervical dysplasia and invasive cervical cancer. ${ }^{1}$

The mean age of women in various studies were also compared. The mean age of the participating women in the present study was 41.48. In the study conducted by Yuonne N Flores et al, ${ }^{3}$ the mean age resulted as 39.5 which are in near proximity with the result of the present study.
Multiparous patients stand a statistically significant risk of acquiring genital HPV infection compared to their non-parous counterparts.

In our study, $97.22 \%$ women had single sexual partner and $2.78 \%$ had multiple sexual partners and only one was the smoker. Her cervical biopsy report was CIN III. This can be accounted for good number of patients being referred for HPV testing in view of abnormal Pap smear.

HPV testing has demonstrated the increased sensitivity for detection of cervical neoplasia. Greater sensitivity associated with greater negative predictive value. High negative predictive value implies it is the best primary screening test. ${ }^{7}$ As there is close association between HPV infection and invasive cancer, identification of high-risk type could be an important tool for screening of carcinoma cervix. Primary screening procedure if not reliable and feasible for developing country, HPV DNA can strengthen the result. ${ }^{8}$ Hence, HPV being the most important causative factor for carcinoma cervix, its detection is an important tool for screening of carcinoma cervix. HPV DNA analysis for high risk group of the virus is more sensitive when compared to Pap smear as a screening method.

World Health Organization and the European research Organization on Genital Infection and Neoplasia in the year 2000 mentioned that HPV testing showed $95-100 \%$ sensitivity for high grade cancer precursors compared with 40-85 \% for traditional cervical cytology (Pap test). This fact strongly suggests HPV testing should be adopted as the primary screening method for women over age $30 .^{5}$

\section{CONCLUSIONS}

The advent of HPV testing has opened the doors for more accurate cervical cancer surveillance strategies than Pap smear. Randomized controlled trials of HPV testing alone have demonstrated that women compared with standard cytologic screening, HPV testing has increased sensitivity for the detection of CIN3 and CIN2 after a single screening round. As compared with Pap testing, HPV testing has greater sensitivity for detection of cervical intraepithelial neoplasia. ${ }^{9}$ HPV testing 
alone for primary screening appears promising in women aged 30 years and older as this group is at greatest risk of developing CIN 3.

The interval between successive smears in cervical cancer screening can be increased considerably for women with morphologically normal smears and negative for high risk oncogenic types. Strictly following up the women who are positive for high risk oncogenic types and testing women negative for HPV at longer intervals could be an effective strategy for cervical cancer screening. The only limitation in the implementation of HPV testing in cervical cancer screening is the cost factor considering low resource setting like our country.

\section{Conflict of Interest: None}

\section{REFERENCES}

1. Bhattacharya N, Shivanna L. Understanding and Management of Premalignant lesions of the Cervix. Obstet and Gynecol Toda 2001; IV: 544 - 549

2. Hatch KD, Berek JS, Addis IB. Intraepithelial Diseases of the cervix, Vagina and Vulva. Berek and Novak's Gynecology, $14^{\text {th }}$ ed. Philadelphia, USA: Lippincott Williams and Wilkins, 2007; 17: 563568.

3. D Yvonne Flores, B E Lazcano, Shah K, A Lörincz, M Hernández ,JSalmerón. Improving cervical cancer screening in Mexico; Results from the Morelos HPV Study; Jul 28, 2003

4. Nasioutziki M, Daniilidis A, Dinas K, Kyrgiou M, Valasoulis G, Loufopoulos PD, Paraskevaidis E, Loufopoulos A, Karakitsos P.The evaluation of p16INK4a immune expression/immunostaining and human papillomavirus DNA test in cervical liquid-based cytological samples.Int J Gynecol Cancer. 2011 Jan;21(1):79-85

5. Matah M, Sareen S. Detection of HPV by PCR-A Novel Step in the Prevention of Cancer Cervix. J ObstetGynaecol India. 2012 Apr; 62(2)

6. A Sinem, AGoker, T Ecemis, R Ali, K T Sanlidag. Human Papilloma Virus Frequency and Genotype Distribution in a Turkish Population; Asian Pacific Journal of Cancer Prevention, 14 (1), 503-506;2013
7. Kumar K, Venkateswaran KI, Bhatla N, Kriplani A, Verma K. Comparative evaluation of smear cytology \& hybrid capture II for the diagnosis of cervical cancer.Department of Pathology \&Gynaecology\& Obstetrics, All India Institute of Medical Sciences, New Delhi, India, 2006

8. S. Khatun et al. Human Papilloma Virus and Other Risk Factors of Carcinoma Cervix. Bangladesh Medical Journal, Vol. 38, No. 1. January 2009

9. Munoz N, Bosch FX, de Sanjose S, Herrero R, Castellsague X, Shah KV et al. Epidemiologic classification of human papillomavirus types associated with cervical cancer. N Engl J Med 2003; 348:518-27 